\title{
Chapter 14 \\ Discard Avoidance by Improving Fishing Gear Selectivity: Helping the Fishing Industry Help Itself
}

\author{
Finbarr G. O’Neill, Jordan Feekings, Robert J. Fryer, Laurence Fauconnet, \\ and Pedro Afonso
}

\begin{abstract}
To address the challenges of the Landing Obligation, fishers need to be able to adjust the selective performance of each fishing operation in response to what they observe on the fishing grounds and to what they bring on board. This will include strategies on where and when to fish but also on how to fish, which we examine here. In particular, we focus on ways to encourage and support fishers to design, develop and test selective gears that will avoid unwanted catches in the first place. To this end, we highlight the necessity to increase awareness of existing solutions, the importance of understanding the capture process and how fish react to fishing gears, and the need to evaluate the economic implications of new gears. We examine the success of science-industry collaborations and emphasise the benefits of a flexible regulatory environment. Looking ahead, the fishing industry needs to keep up-to-date with new technologies that can be used to observe the interaction of fish and their gears and with new approaches to modifying selectivity.
\end{abstract}

Keywords Catch avoidance - Discard reduction - Fish reactions to fishing gear · Industry participation $\cdot$ Selective fishing gears

F. G. O’Neill $(\bowtie) \cdot$ J. Feekings

Technical University of Denmark, National Institute of Aquatic Resources, Hirtshals, Denmark e-mail: barone@aqua.dtu.dk

\section{R. J. Fryer}

Marine Laboratory, Marine Scotland Science, Aberdeen, Scotland, UK

L. Fauconnet · P. Afonso

Marine and Environmental Sciences Centre and OKEANOS Research Unit, Universidade dos Açores, Horta, Portugal 


\subsection{Introduction}

Fishing with selective gears has long been used as a management measure to promote the sustainable exploitation of commercial fisheries. In the European Union and many other jurisdictions, there are measures based on the technical specifications of the gears deployed. For example, minimum mesh size, maximum twine thickness and the use of devices such as square mesh panels and sorting grids have been prescribed in demersal trawl fisheries (Broadhurst 2000; Graham 2010); beam size and number of dredges in beam trawl and dredge fisheries; net height, length and hanging ratio in gill net fisheries (He and Pol 2010); hook size, shape and type of bait in longline fisheries (Løkkeborg et al. 2010); and escape gap dimensions and number of traps in creel and pot fisheries (Thomsen et al. 2010).

The concern of these gear based technical conservation measures has generally been the selectivity or capture of just one or a small number of species. This was usually the main target species but in some instances was a protected species or a marine bird or mammal. The advent of the EU Landing Obligation (LO) brings with it a need to consider the selective performance of a fishing gear in relation to all of the species in the catch to which the Landing Obligation applies.

To develop the range of gears that will be capable of dealing with the specific challenges posed by the Landing Obligation, will require input from fishers, net and gear makers, fishing gear technologists and fish behaviourists. Fishers, in particular, have developed many fishing techniques and fishing gears throughout the world. They can be broadly classified as either active gears, which are towed or are encompassing (Fig. 14.1a, b and c), or static gears, which trap, entangle or hook (Fig. 14.1d, e and f). The design and deployment of these gears are very diverse and depend on fish behaviour, the fishing grounds and the resources available to fishers.

Here, rather than review the many different ways the selective performance of these gears can be improved, we set out a loose framework of initiatives and measures that we believe would support the fishing industry to develop their own selective gears. To facilitate these efforts, we highlight the need for fishers and gear manufacturers to be made aware of existing solutions, to have an understanding of the capture process and an appreciation of how fish react to their gears. We also consider how to encourage the successful development and implementation of more selective gears, the measures that need to be put in place to maximise the likelihood of success of science-industry collaborations, and the benefit of having a flexible regulatory environment. Furthermore, the fishing industry needs to keep up-to-date with technological advances that can be used to observe the interaction of fish and their gears and with new approaches to modifying selectivity. 

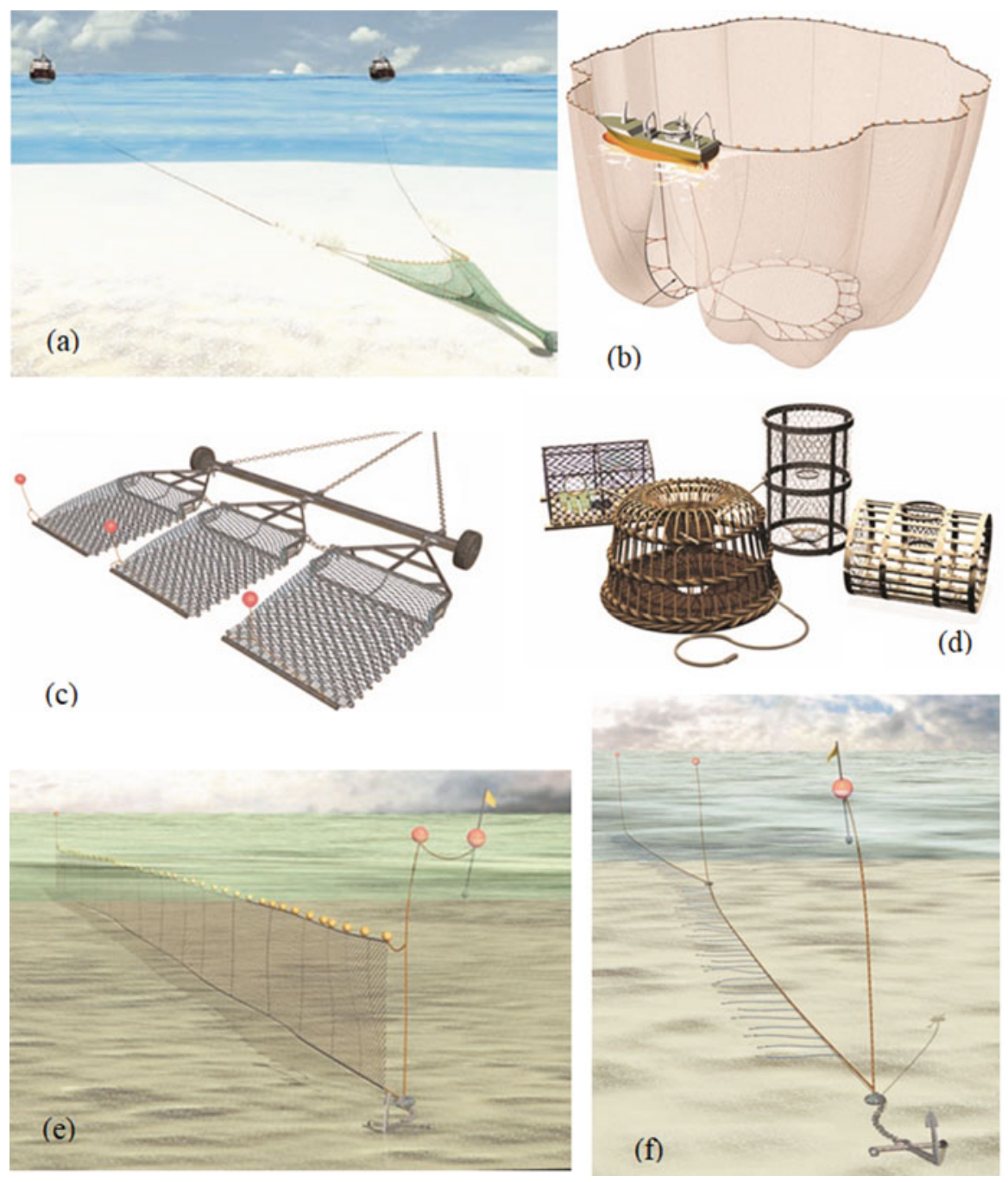

Fig. 14.1 (a) A pair trawl team towing a single demersal trawl. (b) A purse seine net. (c) Three scallop dredges being towed on a single beam. (d) Different types of pots and creels. (e) A gillnet. (f) A longline (Taken from Galbraith et al. 2004)

\subsection{Making Best Use of Existing Information}

There have been many studies of how design changes to fishing gears can alter the size and species profile of the catch. Although these studies may only focus on a limited number of species and the gears tested may only have a local or regional relevance, very often the principles applied have a general significance. Accordingly, there is a lot to be learned from the results of previous trials, and an obvious 
starting point in the development of a selective gear is a thorough review of trials that have already taken place.

The reporting, however, of these studies is varied. Some go unreported, some are reported locally or regionally, while some may be reported internationally (in scientific conferences and peer-reviewed publications). There is also great variation in the level of detail presented: in some cases, it may be only the conceptual idea or a brief design description along with overall results, while in others detailed gear specifications and full haul-by-haul catch data are supplied. To make best use of this information, it needs to be available in an easily accessible way, and, where appropriate, the results should be consolidated and synthesised.

Initiatives such as the DiscardLess factsheets (O’Neill and Mutch 2017, http:// www.discardless.eu/) (Fig. 14.2) and the Gearing up project (https://gearingup.eu/) describe and summarise many of the catch-comparison and selectivity trials that have taken place in the North East Atlantic and adjacent seas and present the results in a searchable format. These initiatives provide an invaluable repository to help fishers, gear manufacturers and fishing gear technologists find practical solutions to the problems they face. However, there is a need to continue to build on them, extend their geographic range and broaden their scope to more gear types (to date they are almost entirely for towed demersal gears). In the first instance, this could be done by linking them to the factsheets that have been produced in some of the regional gear development studies, which have taken place in many countries. There is also a need to ensure the longer-term support and survival of these databases and to secure commitments from relevant bodies (such as ICES, International Council for the Exploration of the Sea or the FAO, United Nations' Food and Agriculture Organisation) to resource them beyond the life of the projects within which they have been developed.

Where sufficient data exists, there may be scope to combine the results from a number of trials to explore a broad range of selective gear options for use in a fishery. Madsen (2007) carried out such an analysis for cod (Gadus morhua), Perez Comas and Pikitch (1994) for a range of gadoid species and ICES (2007) for Norway lobster (Nephrops norvegicus). Another study estimated the proportion of several species that enter a trawl above or below a given height, which will be very useful in designing species selective gears such as low headline or raised footrope trawls (Fryer et al. 2017) (Fig. 14.3). A meta-analysis of target and bycatch species in longline fisheries shows that the performance of circle hooks versus J-hooks is species dependent with higher catch rates of some species with circle hooks and higher rates of other species with J-hooks (Reinhardt et al. 2018), and another assessed the performance of a wide range of bycatch reduction devices in relation to the capture of sharks and rays and the target species (Favaro and Côté 2015).

These types of analyses can be very powerful because they incorporate results from trials where typically only one or two parameters are tested to produce empirical models that predict selection across a wide range of gear parameters, leading to a better understanding of the relative influence of all of these parameters. A meta-analysis of haddock (Melanogrammus aeglefinus) selectivity describes the selective performance of trawl codends in terms of the mesh size, the number of 


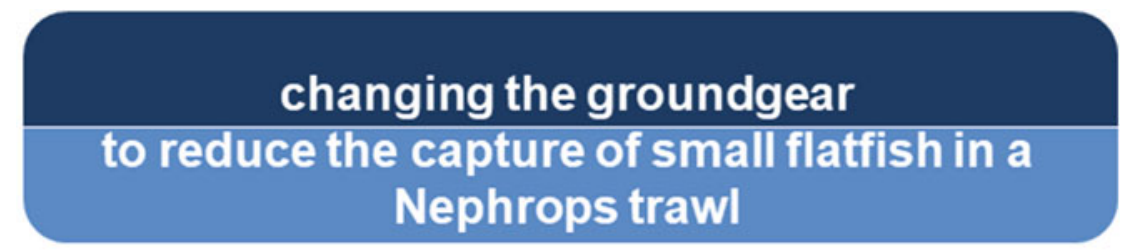

\section{TARGET SPECIES \\ Nephrops and mixed round and flatfish \\ AREA, VESSEL \\ 24 twin trawl catch comparison hauls were carried out in the North Sea on board the Zenith BF106 (671 HP)}

\section{GEAR MODIFICATION}

The catching performance of a low headline 'Letterbox' trawl with $200 \mathrm{~mm}$ spherical bobbins in the $15 \mathrm{~m}$ centre section of the groungear is compared with a similar gear with $200 \mathrm{~mm}$ rockhopper discs in the centre section.

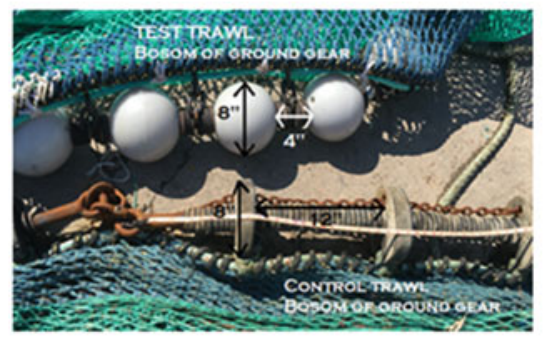

\begin{tabular}{|l|c|c|c|c|}
\hline & \multicolumn{2}{|c|}{ discs } & $\begin{array}{c}\text { bobbin } \\
\text { s }\end{array}$ & \\
\hline & \multicolumn{2}{|c|}{ Total Weight (kg) } & $\%$ diff \\
\hline Lemon Sole & 144 & 148 & 2.9 \\
\hline Plaice & 261 & 257 & -1.4 \\
\hline Witch & 108 & 96 & -11 \\
\hline Megrim & 173 & 132 & -24 \\
\hline Comon dab & 59 & 50 & -16 \\
\hline $\begin{array}{l}\text { Long rough } \\
\text { dab }\end{array}$ & 178 & 81 & -54 \\
\hline
\end{tabular}

\section{marinescotland science}
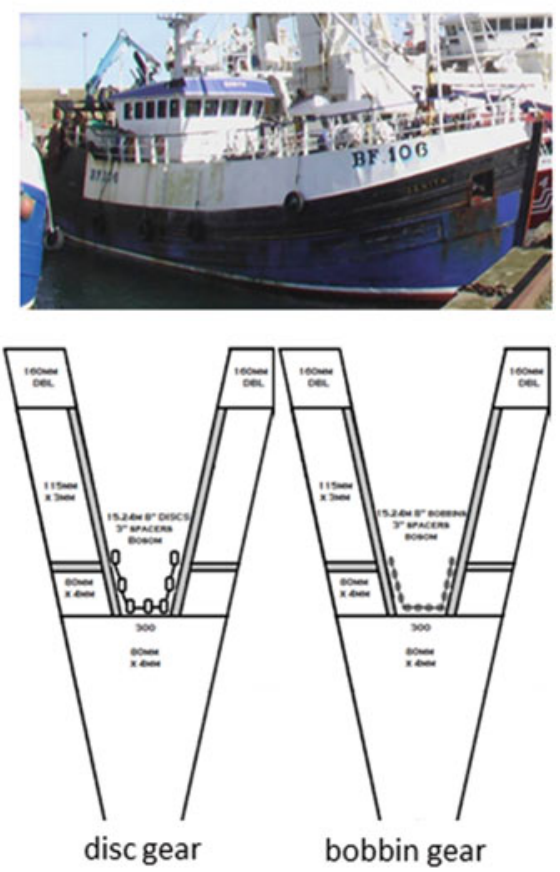

\section{RESULTS}

using the spherical bobbins reduced the catches of flatfish species.

this was length dependent and smaller flatfish were less likely to be retained than larger ones.

For plaice and lemon sole there were greater catches of the larger individuals.

\section{FURTHER INFORMATION}

\section{Matt Kinghorn}

mathew.kinghorn@gov.scot

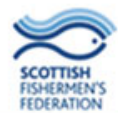

\section{DiscardLess}

Fig. 14.2 Two examples of the DiscardLess factsheets summarising gear trials in Scotland and Turkey (Taken from O'Neill and Mutch 2017) 


\section{Changing mesh shape and increasing mesh} size

\section{to reduce discards in the bottom trawl fishery in the southern Black Sea, Turkey}

TARGET SPECIES

Whiting and red mullet

AREA, VESSEL

21 covered codend hauls were carried out in the southern Black Sea during 2014.

\section{GEAR MODIFICATION}

The catching performance of a standard commercial $\mathbf{4 0} \mathrm{mm}$ diamond mesh codend is compared with the catching performance of

(i) a $36 \mathrm{~mm}$ square mesh codend

(ii) a $40 \mathrm{~mm}$ square mesh codend

(iii) a $40 \mathrm{~mm}$ T90 mesh codend

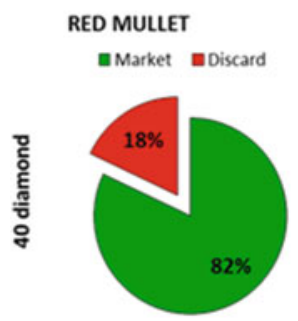

WHITING
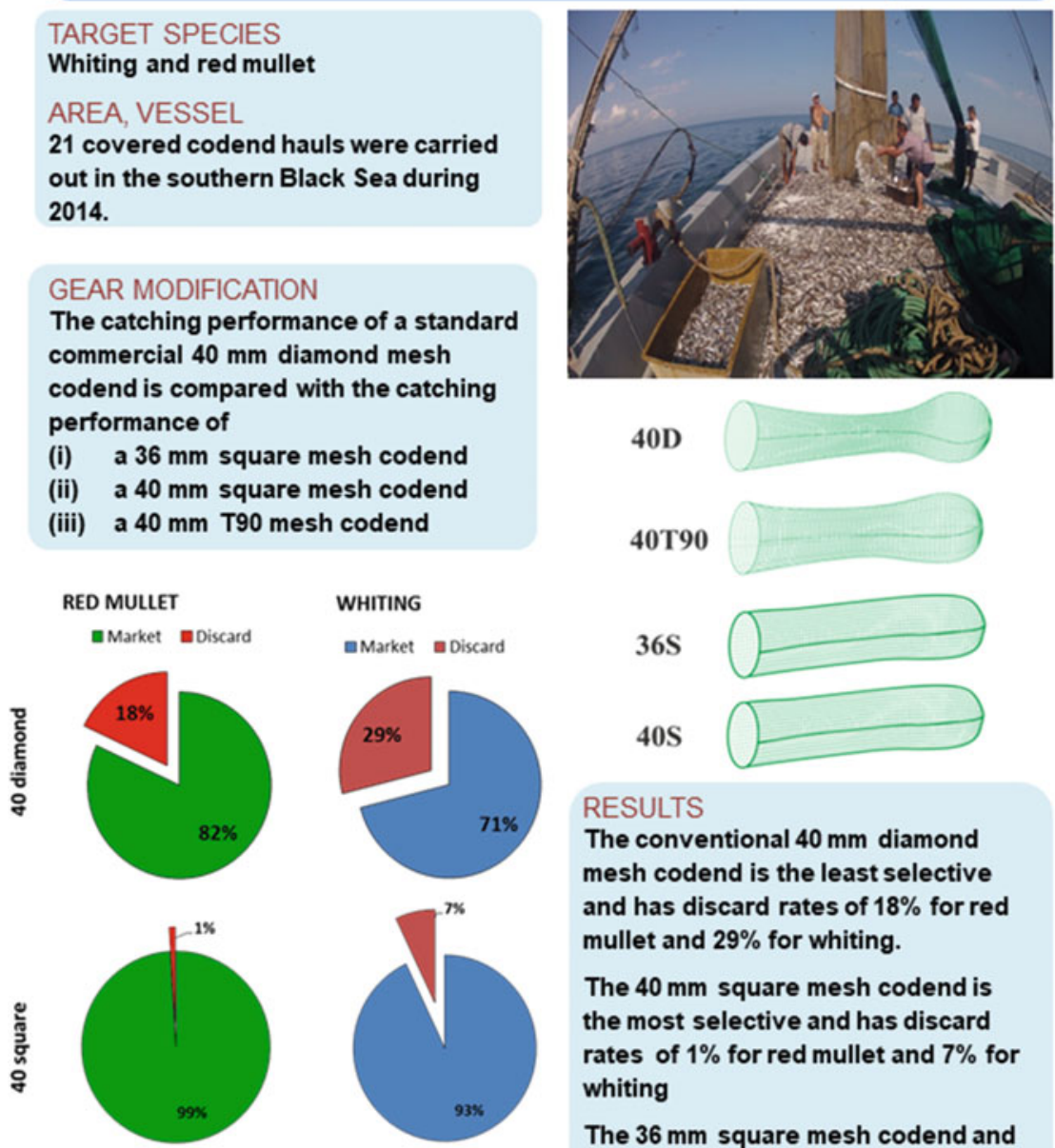

40D

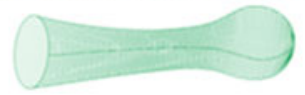

$40 \mathrm{~T} 90$

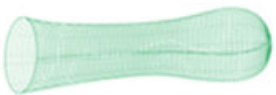

$36 \mathrm{~S}$

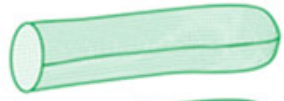

$40 S$

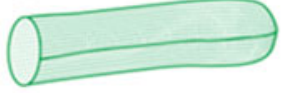

\section{RESULTS}

The conventional $40 \mathrm{~mm}$ diamond mesh codend is the least selective and has discard rates of $18 \%$ for red mullet and $29 \%$ for whiting.

The $40 \mathrm{~mm}$ square mesh codend is the most selective and has discard rates of $1 \%$ for red mullet and $7 \%$ for whiting

The $36 \mathrm{~mm}$ square mesh codend and the $40 \mathrm{~mm}$ T90 codend have intermediate selectivity values.

\section{FURTHER INFORMATION}

Mustafa Zengin.Central Fisheries Research Institute, Trabzon, Turkey. muze5961@gmail.com
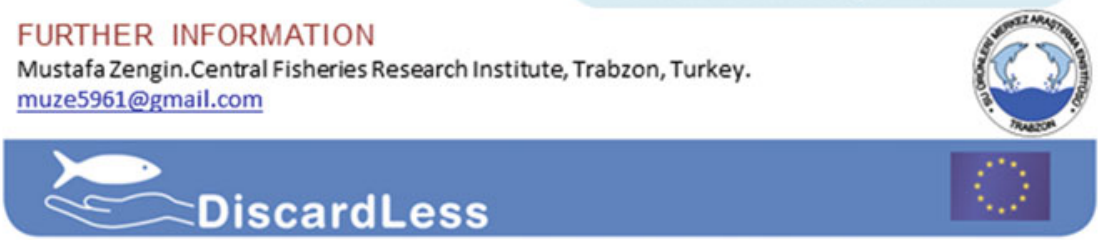

Fig. 14.2 (continued) 

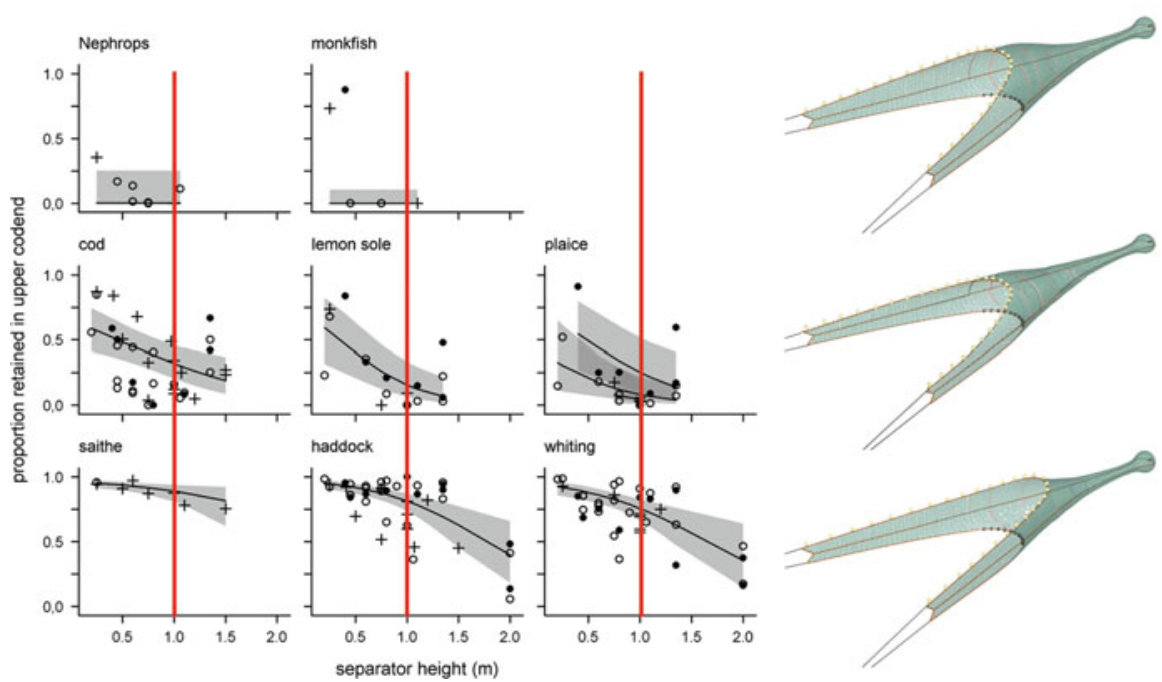

Fig. 14.3 The proportion of fish that will enter a trawl gear above a given height. The vertical red lines indicate the proportion of each species that would enter above a height of $1 \mathrm{~m}$ (Fryer et al. 2017). The trawl gears on the right illustrate how net makers can make use of this type of information to influence the species profile entering a gear by altering the height and position of the headline. The top net is a standard trawl, the middle one is a low headline trawl and the bottom one is a cutaway trawl (Taken from O'Neill and Mutch 2017)

meshes in circumference, the twine diameter of the codend and the position and mesh size of the square mesh panel. It also identified a seasonal dependence on the effectiveness of the panel, which it suggested was related to fish condition (Fryer et al. 2016) (Fig. 14.4).

Underpinning all selective improvements is an understanding of how fish react both close to, and inside, a fishing gear. In addition, for static and baited gears, there is a need to understand how fish search for and catch food (Løkkeborg et al. 2014). Many of the insights into how fish behave during the capture process have come from visual observations by divers (Main and Sangster 1981), underwater camera footage (Piasente et al. 2004; Jones et al. 2008; Bryan et al. 2014; Anders et al. 2017), high frequency acoustic cameras (Rose et al. 2005; Williams et al. 2013), acoustic tracking (Handegard et al. 2003), laboratory experiments (Glass et al. 1993; Breen et al. 2004; Utne-Palm et al. 2018) and from experimental fishing trials at sea (Engås et al. 1998; Ingólfsson and Jørgensen 2006; Ryer et al. 2010).

Again, much of what is known is limited to a few key species, and there is a need to obtain information on how all of the species subject to the Landing Obligation react to fishing gears. There are many comprehensive synthesis and review articles (e.g. Wardle 1993; Broadhurst 2000; Ryer 2008; Winger et al. 2010; Thomsen et al. 2010, Løkkeborg et al. 2010) but often these are aimed at a scientific audience. This information needs to be distilled and presented in a way that is accessible to nonspecialists. O’Neill and Mutch (2017) produce a brief summary of the different 


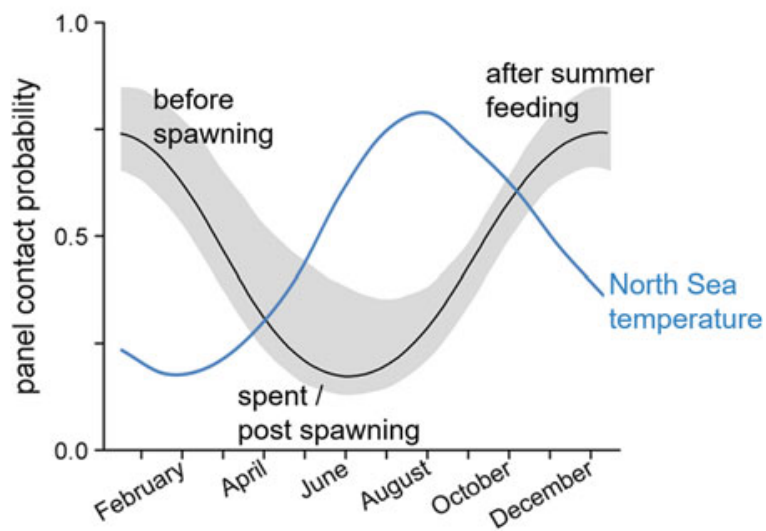

Fig. 14.4 One of the outputs of a meta-analysis of haddock codend selectivity data (Fryer et al. 2016). The panel contact probability, which characterises the effectiveness of the square mesh panel, was shown to vary seasonally. This was out of sync with the average North Sea water temperature but corresponded well with periods of high and low fish condition, suggesting that the selective performance of square mesh panels is related to fish condition

stages of the fish capture process of towed demersal gears, highlighting how different parts of the gear may influence selection and identifying possible design changes which may alter the selectivity of the gear. Their intention was to increase awareness of the possible modifications that can be made to gears so that fishers and net makers can design and develop gears with a selective performance suitable for their particular fishery.

\subsection{Obtaining New Insights and Enhancing the Capacity to Make Real-Time Decisions}

As camera technologies have improved and become miniaturised and less expensive, they are more frequently being used by researchers and fishers to obtain footage of fish reactions to their gears (Struthers et al. 2015). The cheapest and most easy-to-use systems record footage which can be viewed subsequently when the gear is retrieved. Some fishers have made these investments themselves, but in some areas, there are schemes where cameras, specifically designed to be attached to fishing gears, can be borrowed or leased (http://www.fast-track.dk/). The ability to view their own gears, to observe how fish react to them and to see the effects of design changes will enable fishers to find tailored solutions to the specific catch and quota restrictions they are subject to under the LO.

There are also systems which provide real-time footage, but these require transmission cables to the surface which can be difficult to handle and are more expensive. Nevertheless, such an ability would allow fishers to make real-time decisions 
regarding their fishing operation. These could be as simple as deciding to continue or stop fishing, based on observations of what fish are on the ground or entering their gear; or they could be used in conjunction with remotely controllable instruments that, for example, open/close a codend or operate flaps/doors that direct fish into different compartments of a fishing gear.

Current developments in camera technology and image processing will improve the ability to make direct observations of fish and fishing gears. 3D camera systems employing methods such as stereo imaging (Rosen and Holst 2013) or 'time of flight' (which measures the time taken for a light pulse to reach the object and return) are being improved and developed (https://www.utofia.eu/) and may soon permit position and size measurement, even in turbid environments. These systems allied to advances in image analysis, artificial intelligence and machine learning will allow real-time species identification and automatic analysis of acquired images, permitting the skipper or a control system to make real-time decisions (http:// smartfishh2020.eu/; https://www.deepvision.no/).

Acoustic systems have been used in pelagic fisheries, from estimating the size and density of fish schools to tracking individuals, and more recently, to differentiate between and within species (Trenkel et al. 2016). Such developments are likely to be particularly useful for catch identification during the early hauling stages of purse seine fisheries. At present direct methods such as hand-lining and dip-netting are used to determine the species and size profile of the catch, but these can often only be used during the latter stages of hauling, when overcrowding may have occurred and the survival of released catches is likely to be low (Marçalo et al., this volume). Sampling methods, which can be used during the early stages of a haul, such as shooting a 'mini-trawl' into a purse seine (Isaksen 2013) or deploying ROVs fitted with some of the camera systems mentioned above are currently being developed.

Another way of obtaining new insights into gear technology is through the analysis and modelling of data collected in trials. Mixed models are well suited for analysing these data because they estimate the effects of practical importance while accounting for the different sources of variation in the data. The past decade has seen many advances in the statistical methods and software available for fitting mixed models, and they are now routinely used to analyse standard gear trials, such as estimating the selection of a trawl from a covered codend or paired tow experiment, or to compare the catch of one gear with that of another (Millar et al. 2004; Holst and Revill 2009). They also offer exciting possibilities for analysing the data from nonstandard trials, and recently, Browne et al. (2017) used a multinomial mixed model to analyse a quad-rig catch-comparison trial where four test codends were fished simultaneously. The main purpose of the trials was to assess the catch performance of the quad-rig, which is increasingly used in Irish Nephrops fisheries. However, the trials, and the methods for analysing them, suggest how more efficient experiments might be designed in the future, with multiple codends being fished in each haul. Mixed models are also a standard approach to synthesising the results of multiple trials and were used, for example, in the meta-analysis of haddock described in the previous section. A challenge moving forward is to make better use of sparse data, particularly for choke species. In single trials, simplifying assumptions are 
often needed to get models to converge and the power to detect effects can be low. One possibility might be to combine data across multiple trials and to exploit or assume correlations in selection between a data-sparse species and data-rich species that have similar behavioural or morphological characteristics.

\subsection{Successful Development and Implementation}

Innovative selective gears are much more likely to be taken up by the fishing industry if fishers are involved at every stage of the development process, from the conceptual design and experimental refinement through to commercial trials (Kennelly and Broadhurst 2002). In recent years, most industry-science collaborations in Europe have taken such a bottom-up approach (Armstrong et al. 2013; Mortensen et al. 2017), and a number of gears such as the netting grids in the Scottish Nephrops fishery (Kynoch et al. 2012; Drewery et al. 2012) have been successfully introduced. This type of approach creates a sense of ownership and control over the gears developed and often results in a range of technical solutions, all of which may achieve the same objective (Feekings et al. submitted). In contrast, when gears are imposed and introduced into legislation in a top-down approach, with little or no involvement of the fishing industry, there can be a reluctance to use the gear effectively, and indeed, additional alterations may even be made to compromise the selective improvement of the new gear (Krag et al. 2016).

In some cases, incentives have been offered to encourage participation in industry-science collaborations. These can be in the form of financial support for gear construction, or additional effort or quota to offset losses that are incurred during trials or commercial operations (O’Neill et al. 2014). There have also been nonmonetary incentives where maybe a prize is offered, such as the WWF Smart Gear competition (https://www.worldwildlife.org/), or where the publicity or recognition for being involved is considered sufficient reward.

Fishing is an economic activity and uncertainty surrounding the costs and benefits of gear modifications may make vessel owners reluctant to make gear changes due to potential losses in time and revenue both during trial periods and when the gear is being used commercially. Hence, it is very important that fishers can evaluate the financial implications of developing and using more selective gears. To help vessel operators make these assessments, Seafish (a UK Non-Departmental Public Body) has developed a Best Practice Guidance and a Financial Assessment Spreadsheet for industry-led gear trials (http://www.seafish.org/). A fisher can input his own data (on fuel and crew costs, etc.), the cost of the gear modifications/changes and catch data from the corresponding gear trials to assess the financial consequences to his/her business, of testing and introducing new and modified gears.

To develop and introduce selective gears, fishers need to be able to operate in a much more flexible environment. The regulatory regime, in many jurisdictions, is prescriptive, rigid and difficult to change. This can be a serious impediment to gear development as often new or modified gears may not comply with legislation, 
although they may be more selective than what is currently prescribed. Furthermore, to fully address the challenges brought about by the Landing Obligation, fishers will have to be able to react to what they see on the fishing grounds and to modify the selective performance of their gears accordingly. An optimal regulatory approach would be one which is output rather than input driven, that is, one that focusses on what is landed on deck rather than on how it is caught. This would give fishers flexibility to develop and use gears that best suit their specific circumstances (Eliasen et al. 2019).

\subsection{Alternative Technologies to Improve Species and Size Selectivity}

While a lot can be done to develop more selective gears with existing technologies and knowledge, it is also important to consider alternative approaches and new developments. The selective performance of a fishing gear depends on design parameters such as mesh and hook size, and on the response of the species under consideration to the various optical, acoustic, magnetic, electric, hydrodynamic and/or chemical stimuli the gear generates (Popper and Carlson 1998; Jordan et al. 2013; Løkkeborg et al. 2014). In recent years, due to technological developments which can generate and/or modify these stimuli, and an improved understanding of how fish react to them, there has been an increasing focus on harnessing such stimuli to modify fishing gear selectivity.

Light has long been used by fishers to capture squid and pelagic species (Arimoto et al. 2010; Ben-Yami and Pichovich 1988) and, with the onset of robust low-powered LED light sources, it is being considered again in many contexts. Bryhn et al. (2014) increased the catch efficiency of larger cod (Gadus morhua) in pots by using green lights, while Nguyen et al. (2017) improved the catchability of snow crab (Chionoecetes opilio) by using LED lights in their traps. In trials on the west coast of the USA, Hannah et al. (2015) were able to reduce the capture of some fish species by up to $90 \%$ with no loss of ocean shrimp (Pandalus jordani) by placing LED lights on the fishing line of their shrimp trawls. There have also been successful trials with luminous netting materials, fibre optic cables and lasers to direct fish into or within a trawl (Karlsen et al. 2018; O'Neill et al. 2018; Hreinsson et al. 2018). To fully exploit the potential of light to improve the selective performance of commercial fishing gears, more research needs to be done on how parameters such as the wavelength, intensity, polarisation and strobing of light can be used to modify the behavioural reaction of fish (Ben-Yami 1976; Marchesan et al. 2005; Arimoto et al. 2010; Königson et al. 2002).

Sound has been used to guide, ranch, condition and aggregate fish in fishing operations (Yan et al. 2010). It has also been used to deter and repel fish and marine mammals from water intake pipes and fishing gears. In gillnet fisheries, active devices such as pingers, which emit an acoustic signal, have been attached to 
gears to reduce the bycatch of cetaceans by alerting them to the presence of the gear (Rihan 2010). There have been many advances of parametric sound technology where a 'beam' of sound is transmitted directionally and focused at high intensity on to a relatively small area (Gan et al. 2012). These developments open up the possibility of creating 'walls' or surfaces of sound which could be used to direct and herd fish and marine mammals in a more focussed way. There are also passive approaches where the acoustic reflectivity of the gear is enhanced by treating the netting material or attaching acoustic reflectors to the gear so that they are more easily detected by echo-locating species (He and Pol 2010).

In longline fisheries there have been attempts to take advantage of elasmobranchs' ability to detect weak electromagnetic fields to reduce their capture by using electropositive metals and magnets (Robbins et al. 2011; Kaimmer and Stoner 2008; O'Connell et al. 2014). While success has been limited thus far, and there are issues related to manufacturing costs, deterioration in water and large-scale deployment (Favaro and Côté 2015), there is the possibility that alternative metals and compounds will offer cheaper and cost-effective solutions (O'Connell et al. 2014). In trawl fisheries, electricity has been used to increase catchability by stimulating benthic species from the seafloor, to direct and aggregate fish so that they can be caught more easily by conventional means and to improve the performance of selective devices by exploiting species and size differences in their behavioural responses (Polet 2010). In the southern North Sea flatfish fishery, electrodes produce an electric field which induces a cramp response that bends fish in a U-shape, making it easier for the ground gear to get underneath them so they enter the trawl (van Marlen et al. 2014; Depestele et al. 2018). Other examples of using electricity in trawl fisheries include the Belgian and Chinese shrimp fisheries (Polet et al. 2005; $\mathrm{Yu}$ et al. 2007) and the razor clam (Ensis spp.) fishery in the West of Scotland (Murray et al. 2016).

There are a number of examples where the hydrodynamics of towed gears have been exploited to improve selectivity. Veil nets in shrimp fisheries, rising panels in codend extensions and the flex deflector modify the flow in the gear to direct fish and crustaceans onto or closer to grids and square mesh panels (Graham 2003; Santos et al. 2016). The Hydrodredge deflects a water flow on to the seabed to raise great scallops (Pecten maximus) from the seabed (Shephard et al. 2009), and Jordan et al. (2013) suggest that water jets directed downwards, ahead of a trawl gear could elicit an early response from elasmobranchs, allowing them to avoid capture. There is also potential to create regions of low flow behind screens and bluff bodies and turbulent regions which, if the associated vortices are an appropriate strength and size, can be used to encourage fish to hold station and perhaps increase their probability of contact with a selectivity device (Liao 2007; Laird et al. 2016).

The gustatory and olfactory senses are of particular importance in baited gears and Løkkeborg et al. (2010) and Thomsen et al. (2010) highlighted the potential of artificial baits, longer-lasting baits and a better understanding of species-specific differences in bait performance to improve the selective performance of longline and pot fisheries. Gilman et al. (2008) have shown that using fish instead of squid for bait reduced shark bycatch in pelagic longlines, while Stroud et al. (2014) have shown 
Table 14.1 Technologies that may be useful in elasmobranch bycatch mitigation by gear and sensory modality

\begin{tabular}{|c|c|c|c|c|}
\hline Sensory modality & $\begin{array}{l}\text { Baited hook and line } \\
\text { (longline) }\end{array}$ & Gill net & Trawl & Purse seine \\
\hline \multirow[t]{3}{*}{ Olfaction } & $\begin{array}{l}\text { Surfactants, } \\
\text { semiochemicals }\end{array}$ & \multirow[t]{3}{*}{$\begin{array}{l}\text { Surfactants, } \\
\text { semiochemicals }\end{array}$} & & \multirow{3}{*}{$\begin{array}{l}\text { Remote } \\
\text { attraction/ } \\
\text { bait } \\
\text { stations }\end{array}$} \\
\hline & Bait type & & & \\
\hline & Dead sharks & & & \\
\hline Hearing & Not recommended & & & \\
\hline \multirow[t]{4}{*}{ Vision } & $\begin{array}{l}\text { Light sticks: wavelength } \\
\text { and flicker }\end{array}$ & Net illumination & \multirow[t]{4}{*}{$\begin{array}{l}\text { Flashing } \\
\text { lights }\end{array}$} & \\
\hline & Bait colour & Net colour & & \\
\hline & Leader type/colour & \multirow[t]{2}{*}{ Predator models } & & \\
\hline & Dead sharks & & & \\
\hline $\begin{array}{l}\text { Mechanosensory } \\
\text { lateral line/pit } \\
\text { organs }\end{array}$ & & & Water jets & \\
\hline Electrosensory & $\begin{array}{l}\text { Magnets, lanthanide } \\
\text { metals, battery-powered } \\
\text { electric devices }\end{array}$ & $\begin{array}{l}\text { Powered electric field } \\
\text { 'barrier' Magnetic } \\
\text { field 'barrier' }\end{array}$ & $\begin{array}{l}\text { Electric } \\
\text { pulse } \\
\text { generators }\end{array}$ & \\
\hline Other & & Pre-net fence (tactile) & & \\
\hline
\end{tabular}

Taken from Jordan et al. (2013)

that a necromone produced from putrefied shark tissue was $100 \%$ repellent to competitively feeding Caribbean reef sharks (Carcharhinus perezi) and blacknose sharks (Carcharhinus acronotus).

It is evident that there is great scope to make better use of all the senses that target and bycatch species have. Again, it is very important that this information is relayed to fishers, gear manufacturers, gear technologists and fisheries managers in a readily accessible way. Jordan et al. (2013) provide a very useful summary table which identifies new and existing technologies that should undergo further testing for use in elasmobranch bycatch mitigation. They classify potential solutions for a range of gear types in terms of the sensory modality that the fish will use and which we reproduced here (Table 14.1) as an example of what could be very usefully extended to other species.

\subsection{In Summary}

The specific challenges posed by the Landing Obligation will depend on the catching performance of the fishing gears, the total allowable catches and the size profile and spatial distribution of the stocks. Hence, not only will the issues that arise vary from year to year and from fishery to fishery, they will most likely vary from vessel to vessel and from trip to trip. As a result, the most practicable way forwards is one where each fisher is in a position to adjust the selective performance of each fishing 
operation. This will include strategies on where and when to fish, as addressed by Reid et al. (this volume), but also, on how to fish, as is set out here in this chapter. In this regard, fishers need to be able to modify the selective performance of their fishing gear in response to what they observe on the fishing grounds and to what they bring on board. They need to be made aware of existing solutions and have an appreciation of how their gears catch. This includes understanding the mechanistic aspects of their gear's performance (and its dependence on parameters such mesh or hook size, etc.) and an awareness of the sensory stimuli generated by fishing gears and the corresponding responses of the species they catch. They need to operate in a regime which encourages their participation in a meaningful way and in a regulatory environment that permits them to develop and use new and modified gears.

Ultimately, fishers are best placed to identify the challenges brought about by the landing obligation, and in collaboration with gear makers, fishing gear technologists and fish behaviourists, are those most likely to find solutions that are both acceptable and effective.

Acknowledgements Part of this work has received funding from the Horizon 2020 Programme under grant agreement DiscardLess number 633680. This support is gratefully acknowledged.

\section{References}

Anders, N., Fernö, A., Humborstad, O.-B., Løkkeborg, S., Rieucau, G., Utne-Palm, A.C. (2017). Size-dependent social attraction and repulsion explains the decision of Atlantic cod Gadus morhua to enter baited pots. Journal of Fish Biology, 91(6), 1569-1581.

Arimoto, T., Glass, C.W., Zhang, X. (2010). Fish vision and its role in fish capture. In P. He (Ed.), Behavior of marine fishes: Capture processes and conservation challenges. Oxford: WileyBlackwell.

Armstrong, M.J., Payne, A.I.L., Deas, B., Catchpole, T.L. (2013). Involving stakeholders in the commissioning and implementation of fishery science projects: Experiences from the UK Fisheries Science Partnership. Journal of Fish Biology, 83, 974-996.

Ben-Yami, M. (1976). Fishing with light. FAO fishing manuals. Fishing News Books Limited, Surrey.

Ben-Yami, M., Pichovich, A. (1988). Attracting fish with light (FAO Training Series No. 14). Rome: FAO.

Breen, M., Dyson, J., O’Neill, F.G., Jones, E., Haigh, M. (2004). The swimming performance of haddock at prolonged and sustained swimming speeds, and its role in their capture by towed fishing gears. ICES Journal of Marine Science, 61, 1071-1079.

Broadhurst, M.K. (2000). Modifications to reduce bycatch in prawn trawls: A review and framework for development. Reviews in Fish Biology and Fisheries, 10(1), 27-60.

Browne, D., Minto, C., Cosgrove, R., Burke, B., McDonald, D., Officer, R., Keatinge, M. (2017). A general catch comparison method for multi-gear trials: Application to a quad-rig trawling fishery for Nephrops. ICES Journal of Marine Science, 74, 1458-1468.

Bryan, D.R., Bosley, K.L., Hicks, A.C., Haltuch, M.A., Wakefield, W.W. (2014). Quantitative video analysis of flatfish herding behavior and impact on effective area swept of a survey trawl. Fisheries Research, 154, 120-126. 
Bryhn, A.C., Konigson, S.J., Lunneryd, S.-G., Bergenius, M.A.J. (2014). Green lamps as visual stimuli affect the catch efficiency of floating cod (Gadus morhua) pots in the Baltic Sea. Fisheries Research, 157, 187-192.

Depestele, J., Degrendele, K., Esmaeili, M., Ivanović, A., Kröger, S., O’Neill, F.G., Parker, R., Polet, H., Roche, M., Teal, L.R., Vanelslander, B., Rijnsdorp, A.D. (2018). Comparison of mechanical disturbance in soft sediments due to tickler-chain SumWing trawl versus electrofitted PulseWing trawl. ICES Journal of Marine Science. https://doi.org/10.1093/icesjms/fsy 124.

Drewery, J., Watt, M., Kynoch, R.J., Edridge, A., Mair, J., O'Neill, F.G. (2012). Catch comparison trials of the Flip Flap netting grid trawl. Marine Scotland Science Report 08/12.

Eliasen, S.Q., Feekings, J., Krag, L., Veiga Malta, T., Mortensen, L.O., Ulrich, C. (2019). The landing obligation calls for a more flexible technical gear regulation in EU waters - Greater industry involvement could support development of gear modifications. Marine Policy. 173-180.

Engås, A., Jørgensen, T., West, C.W. (1998). A species-selective trawl for demersal gadoid fisheries. ICES Journal of Marine Science, 55, 835-845.

Favaro, B., Côté, I.M. (2015). Do by-catch reduction devices in longline fisheries reduce capture of sharks and rays? A global meta-analysis. Fish and Fisheries, 16, 300-309.

Feekings, J.P., O’Neill, F.G., Krag, L.A., Ulrich, C., Veiga-Malta, T. (submitted). An evaluation of European initiatives established to encourage industry-led development of selective fishing gears. Fisheries Management and Ecology.

Fryer, R.J., O’Neill, F.G., Edridge, A. (2016). A meta-analysis of haddock size-selection data. Fish and Fisheries, 17, 358-374. https://doi.org/10.1111/faf.12107

Fryer, R.J., Summerbell, K., O’Neill, F.G. (2017). A meta-analysis of vertical stratification in demersal trawl gears. Canadian Journal of Fisheries and Aquatic Sciences, 74, 1243-1250.

Galbraith, R.D. and Rice, A. after Strange, E.S. (2004). An introduction to commercial fishing gear and methods used in Scotland. Scottish Fisheries Information Pamphlet. No. 25, 2004.

Gan, W.S., Yang, J., Kamakura, T. (2012). A review of parametric acoustic array in air. Applied Acoustics, 73, 1211-1219.

Gilman, E., Clarke, S., Brothers, N., Alfaro-Shigueto, J., Mandelman, J., Mangel, J., Petersen, S., Piovano, S., Thomson, N., Dalzell, P., Donoso, M., Goren, M., Werner, T. (2008). Shark interactions in pelagic longline fisheries. Marine Policy, 32, 1-18.

Glass, C.W., Wardle, C.S., Gosden, S.J. (1993). Behavioural studies of the principles underlying mesh penetration by fish. ICES Marine Science Symposia, 196, 92-97.

Graham, N. (2003). By-catch reduction in the brown shrimp, Crangon crangon, fisheries using a rigid separation Nordmore grid (grate). Fisheries Research, 59, 393-407.

Graham, N. (2010). Technical measures to reduce bycatch and discards in trawl fisheries. In P. He (Ed.), Behavior of marine fishes: Capture processes and conservation challenges. Oxford: Wiley-Blackwell.

Handegard, N.O., Michalsen, K., Tjøstheim, D. (2003). Avoidance behaviour in cod (Gadus morhua) to a bottom-trawling vessel. Aquatic Living Resources, 16, 265-270.

Hannah, R.W., Lomeli, M.J.M., Jones, S.A. (2015). Tests of artificial light for bycatch reduction in an ocean shrimp (Pandalus jordani) trawl: Strong but opposite effects at the footrope and near the bycatch reduction device, Fisheries Research, 170, 60-67.

He, P., \& Pol, M. (2010). Fish behavior near gillnets: Capture processes and influencing factors. In P. He (Ed.), Behavior of marine fishes: Capture processes and conservation challenges. Oxford: Wiley-Blackwell.

Holst, R., Revill, A., (2009). A simple statistical method for catch comparison studies. Fisheries Research, 95, 254-259.

Hreinsson, E., Karlsson, H., Gudmundsson, G., Jonsdottir, H., Thorhallsson, T. (2018). Catching Northern Prawn without benthic contact. ICES WGFTFB 2018 REPORT. ICES CM 2018/ EOSG:12.

ICES. (2007). Report of the Workshop on Nephrops Selection (WKNEPHSEL). ICES CM 2007/ FTC 1, 49pp. 
Ingólfsson, Ó.A., \& Jørgensen, T. (2006). Escapement of gadoid fish beneath a commercial bottom trawl: Relevance to the overall trawl selectivity. Fisheries Research, 79, 303-312.

Isaksen, B. (2013). Fish sampling by shooting a mini trawl into the purse-seine net. Norwegian Institute of Marine Research, Havforskningsnytt nr. 2-2013.

Jones, E.G., Summerbell, K., O'Neill, F.G. (2008). The influence of towing speed and fish density on the behaviour of Haddock in a trawl cod-end. Fisheries Research, 94, 166-174.

Jordan, L.K. Mandelman, J.W. McComb, D.M. Fordham, S.V., Carlson, J.K., Werner, T.B. (2013). Linking sensory biology and fisheries bycatch reduction in elasmobranch fishes: A review with new directions for research. Conservation Physiology, 1(1).

Kaimmer, S., Stoner, A.W., (2008). Field investigation of rare-earth metal as a deterrent to spiny dogfish in the Pacific halibut fishery. Fisheries Research, 94, 43-47.

Karlsen, J.D., Melli, V., Krag, L.A. (2018). The luminous net VISIONET - A guiding swimway to the exit or a stressor? ICES WGFTFB 2018 REPORT. ICES CM 2018/EOSG:12

Kennelly, S.J., \& Broadhurst, M.K. (2002). By-catch begone: Changes in the philosophy of fishing technology. Fish and Fisheries, 3(4), 340-355.

Königson, S., Fjälling, A. \& Lunneryd, SG., (2002). Reactions in individual fish to strobe light. Field and aquarium experiments performed on whitefish (Coregonus lavaretus). Hydrobiologia, $483,39-44$.

Krag, L.A., Herrmann, B., Feekings, J.P., Karlsen, J.D. (2016). Escape panels in trawls - A consistent management tool? Aquatic Living Resources, 29, 306.

Kynoch, R.J., Edridge, A., O'Neill, F.G. (2012). Catch comparison trials with the Faithlie Cod Avoidance Panel (FCAP). Scottish Marine and Freshwater Science, 3(8).

Laird, A., Cahill, J., Liddell, B. (2016). Kons covered fisheyes BRD trial. Report Northern Prawn Fishery. http://www.afma.gov.au/wp-content/uploads/2017/05/Kons-Covered-Fisheyes-BRDTrial-Report-Northern-Prawn-Fishery-2016_FINAL.pdf.

Liao, J.C. (2007). A review of fish swimming mechanics and behaviour in altered flows. Philosophical Transactions of the Royal Society, 362, 1973-1993.

Løkkeborg, S., Fernö, A., Humborstad, O.-B. (2010). Fish behavior in relation to longlines. In P. He (Ed.), Behavior of marine fishes: Capture processes and conservation challenges. Oxford: Wiley-Blackwell.

Løkkeborg, S., Siikavuopio, S.I., Humborstad, O.-B., Utne-Palm, A.C., Ferter, K. (2014). Towards more efficient longline fisheries: Fish feeding behaviour, bait characteristics and development of alternative baits. Reviews in Fish Biology and Fisheries, 24, 985-1003.

Madsen, N. (2007). Selectivity of fishing gears used in the Baltic Sea cod fishery. Reviews in Fish Biology and Fisheries, 17, 517-544.

Main, J., \& Sangster, G.I. (1981). A study of the fish capture process in a bottom trawl by direct observations from a towed underwater vehicle (Scottish fisheries research report No. 23). Aberdeen: Department of Agriculture and Fisheries for Scotland, 23 pp.

Marçalo, A., Breen, M., Tenningen, M., Onandia, I., Arregi, L., Gonçalves, J.M.S. (this volume). Mitigating slipping related mortality from purse seine fisheries for small pelagic fish: Case studies from European Atlantic waters. In S.S. Uhlmann, C. Ulrich, S.J. Kennelly (Eds.), The European Landing Obligation - Reducing discards in complex multi-species and multijurisdictional fisheries. Cham: Springer.

Marchesan, M., Spoto, M., Verginella, M., Ferrero, E.A. (2005). Behaviour effects of atificial light on fish species of commercial interest. Fisheries Research, 73, 171-185.

Millar, R.B., Broadhurst, M.K., MacBeth, W.G. (2004). Modelling between-haul variability in the size selectivity of trawls. Fisheries Research, 67 171-181.

Mortensen, L.O., Ulrich, C., Qvist Eliasen, S., Olesen, H.J. (2017). Reducing discards without reducing profit: Free gear choice in a Danish result-based management trial. ICES Journal of Marine Science, 74(5), 1469-1479.

Murray, F., Copland, P., Boulcott, P., Robertson, M., Bailey, N. (2016). Impacts of electrofishing for razor clams (Ensis spp.) on benthic fauna. Fisheries Research, 174, 40-46. 
Nguyen, K.Q., Winger, P.D., Morris, C., Grant, S.M. (2017). Artificial lights improve the catchability of snow crab (Chionoecetes opilio) traps. Aquaculture and Fisheries, 2(3), $124-133$.

O'Connell, C.P., Stroud, E.M., He, P. (2014). The emerging field of electrosensory and semiochemical shark repellents: Mechanisms of detection, overview of past studies, and future directions. Ocean \& Coastal Management, 97, 2-11.

O’Neill, F.G., \& Mutch, K. (2017). Selectivity in trawl fishing gears Scottish Marine and Freshwater. Science, $8(1)$.

O’Neill, F.G., Lines, E.K., Kynoch, R.J., Fryer, R.J., Maguire, S. (2014). A short-term economic assessment of incentivised selective gears. Fisheries Research, 157, 13-23.

O'Neill, F.G., Summerbell, K., Barros, L. (2018). Some recent trials with illuminated grids. ICES WGFTFB 2018 REPORT. ICES CM 2018/EOSG:12.

Perez Comas, J.A., \& Pikitch, E.K. (1994). The predictive power of empirical relationships describing size selectivity, with application to gadoid fish. Fisheries Research, 20, 151-164.

Piasente, M., Knuckey, I.A., Eayrs, S., McShane, P.E. (2004). In situ examination of the behaviour of fish in response to demersal trawl nets in an Australian trawl fishery. Marine and Freshwater Research, 55, 825-835.

Polet, H. (2010). Electric senses of fish and their application in marine fisheries. In P. He (Ed.), Behavior of marine fishes: Capture processes and conservation challenges. Oxford: WileyBlackwell.

Polet, H., Delanghe, F., Verschoore, R. (2005). On electrical fishing for brown shrimp (Crangon crangon) II. Sea trials Fisheries Research, 72, 13-27.

Popper, A.N., \& Carlson, T.J. (1998). Application of sound and other stimuli to control fish behavior. Transactions of the American Fisheries Society, 127, 673-707.

Reid, D.G., Calderwood, J., Afonso, P., Fauconnet, L., Pawlowski, L., Plet-Hansen, K.S., Radford, Z., Robert, M., Rochet, M.-J., Ordines, F., Rueda, L., Mortensen, L., Ulrich, C., Vermard, Y. (this volume). The best way to reduce discards is never to catch them in the first place! In S.S. Uhlmann, C. Ulrich, S.J. Kennelly (Eds.), The European Landing Obligation - Reducing discards in complex multi-species and multi-jurisdictional fisheries. Cham: Springer.

Reinhardt, J.F., Weaver, J., Latham, P.J., Dell'Apa, A., Serafy, J.E., Browder, J.A., Christman, M., Foster, D.G., Blankinship, D.R. (2018). Catch rate and at-vessel mortality of circle hooks versus J-hooks in pelagic longline fisheries: A global meta-analysis. Fish and Fisheries, 19, 413-430.

Rihan, D. (2010). Measures to reduce interactions of marine megafauna with fishing operations. In P. He (Ed.), Behavior of marine fishes: Capture processes and conservation challenges. Oxford: Wiley-Blackwell.

Robbins, W.D., Peddemors, V.M., Kennelly, S.J. (2011). Assessment of permanent magnets and electropositive metals to reduce the line-based capture of Galapagos sharks, Carcharhinus galapagensis. Fisheries Research, 109, 100-106.

Rose, C., Stoner, A.W., Matteson, K. (2005). Use of high-frequency imaging sonar to observe fish behaviour near baited fishing gear. Fisheries Research, 76, 291-304.

Rosen, S., \& Holst, J.C. (2013). DeepVision in-trawl imaging: Sampling the water column in four dimensions. Fisheries Research, 148, 64-73.

Ryer, C.H. (2008). A review of flatfish behavior relative to trawls. Fisheries Research, 90(2008), $138-146$.

Ryer, C.H., Rose, C.S., \& Iseri, P.J. (2010). Flatfish herding behaviour in response to trawl sweeps: A comparison of diel responses to conventional sweeps and elevated sweeps. Fishery Bulletin, $108,145-154$.

Santos, J., Herrmann, B., Mieske, B., Stepputtis, D., Krumme, U., Nilsson, H., (2016). Reducing flatfish bycatch in roundfish fisheries. Fisheries Research 184, 64-73.

Shephard, S., Goudey, C.A., Read, A., Kaiser, M.J. (2009). Hydrodredge: Reducing the negative impacts of scallop dredging. Fisheries Research, 95, 206-209. 
Stroud, E.M., O'Connell, C.P., Rice, P.H., Snow, N.H., Barnes, B.B., Elshaer, M.R., Hanson, J.E. (2014). Chemical shark repellent: Myth or fact? The effect of a shark necromone on shark feeding behavior. Ocean \& Coastal Management, 97, 50-57.

Struthers, D.P., Danylchuk, A.J, Wilson, A.D.M., Cooke, S.J., (2015). Action cameras: Bringing aquatic and fisheries research into view. Fisheries, 40(10), 502-512.

Thomsen, B., Humborstad, O.-B., Furevik, D.M. (2010). Fish pots: Fish behavior, capture processes, and conservation issues. In P. He (Ed.), Behavior of marine fishes: Capture processes and conservation challenges. Oxford: Wiley-Blackwell.

Trenkel, V.M., Handegard, N.O., Weber, T.C. (2016). Observing the ocean interior in support of integrated management. ICES Journal of Marine Science, 73, 1947-1954.

Utne-Palm, A.C., Breen, M., Løkkeborg, S., Humborstad, O.-B. (2018). Behavioural responses of krill and cod to artificial light in laboratory experiments. PLOS ONE, 13(1), e0190918. https:// doi.org/10.1371/journal.pone.0190918

van Marlen, B., Wiegerinck, J.A.M., van Os-Koomen, E., van Barneveld, E. (2014). Catch comparison of pulse trawls and a tickler chain beam trawl. Fisheries Research, 151, 57-69.

Wardle, C.S. (1993). Fish behaviour and fishing gear. In T.J. Pitcher (Ed.), Behaviour of teleost fishes (pp. 609-643). London: Chapman \& Hall.

Williams, K., Wilson, C.D., Horne, J.K. (2013). Walleye pollock (Theragra chalcogramma) behavior in midwater trawls. Fisheries Research, 143, 109-118.

Winger, P.D., Eayrs, S., Glass, C.W. (2010). Fish behavior near bottom trawls. In P. He (Ed.), Behavior of marine fishes: Capture processes and conservation challenges. Oxford: WileyBlackwell.

Yan, H.Y., Anraku, K., Babaran, R.P. (2010). Hearing in marine fish and its application in fisheries. In P. He (Ed.), Behavior of marine fishes: Capture processes and conservation challenges. Oxford: Wiley-Blackwell.

Yu, C., Chen, Z., Chen, L., He, P. (2007). The rise and fall of electrical beam trawling for shrimp in the East China Sea: Technology, fishery, and conservation implications. ICES Journal of Marine Science, 64, 1592-1597.

Open Access This chapter is licensed under the terms of the Creative Commons Attribution 4.0 International License (http://creativecommons.org/licenses/by/4.0/), which permits use, sharing, adaptation, distribution and reproduction in any medium or format, as long as you give appropriate credit to the original author(s) and the source, provide a link to the Creative Commons license and indicate if changes were made.

The images or other third party material in this chapter are included in the chapter's Creative Commons license, unless indicated otherwise in a credit line to the material. If material is not included in the chapter's Creative Commons license and your intended use is not permitted by statutory regulation or exceeds the permitted use, you will need to obtain permission directly from the copyright holder.

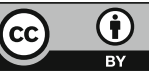

